\title{
The Paradox of the Heavy-Handed Insurgent: Public Support for the Taliban Among Afghan Pashtuns
}

\author{
Karl Kaltenthaler \\ University of Akron and Case Western Reserve University
}

Arie W. Kruglanski

University of Maryland

Austin J. Knuppe

Utah State University

\begin{abstract}
Afghanistan is a profoundly insecure country, with a very high rate of insurgent violence, affecting large swathes of the population. Despite contributing to physical and economic insecurity across the country, Taliban insurgents have succeeded in creating what we call the "paradox of the heavyhanded insurgent." Insurgents use attacks on government-controlled areas to generate public support by fostering a reputation for effective security provision for the civilian population under its control. For civilians who have a strong unmet need for physical security-especially those in rural and contested communities - heavy-handed insurgents are preferable to government forces who are perceived as either incompetent or unwilling to provide governance. We test this argument using data from the 2018 Asia Society Survey of the Afghan People. We find that the most important factor driving sympathy for the Taliban among Afghan Pashtuns is their sense of insecurity where they live. This indicates that an insurgent group that wears down government forces and weakens their ability to provide public goods and services can actually benefit by appearing as the more viable alternative for governance despite their heavy-handed tactics.
\end{abstract}

Keywords:

Afghanistan, counterinsurgency, civilian support, public opinion, fragile states

Word Count: 9,245 


\section{Introduction}

The 2001-2021 Taliban insurgency in Afghanistan came at a tremendous cost to the civilian population. More than 100,000 civilians lost their lives or were wounded in the war that followed the removal of the Taliban from power by a US-led coalition in December of 2001. ${ }^{1}$ The conflict disproportionately affected rural Pashtuns in southern and eastern provinces - especially Helmand, Kandahar, and Patika — where the Pashtuns represent the dominant ethnic group. Despite the high cost of the conflict on Pashtun communities, recent surveys conducted in Afghanistan have shown strong and consistent support for the Taliban among about a quarter of Pashtun civilians. ${ }^{2}$ Remarkedly, sympathy for the Taliban remained strong even among Pashtuns living in communities where insurgent attacks were common. Why did some Pashtun civilians in communities affected by Taliban violence sympathize with the insurgents who were contributing to such insecurity?

Theorists and practitioners of counterinsurgency doctrine (COIN) attribute civilian sympathy for insurgents to three key factors: territorial control, coethnicity bias, and civilian targeting. ${ }^{3}$ In communities marked by high levels of indiscriminate violence attributed to insurgents, however, civilian support for insurgents should drop. Instead, we observe consistent support for the Taliban among coethnics who have suffered from the violent effects of the conflict. As the Afghan case demonstrates, existing explanations fail to account for how civilians are often forced to choose the "best worst option" for local governance. Above and beyond a shared social identity or presence in the community, civilians detect and respond to threats based on their judgements about armed groups' resolve and competence to provide order.

Existing work yields important insights into what factors shape civilian support for armed groups. The paradox of why insurgents gain popular support among vulnerable civilians despite 
their contribution to indiscriminate violence, however, remains understudied. In response, we argue that the Taliban actually won support from those in Afghanistan who felt most insecure because of the underlying conditions driven by the Taliban's violent efforts to overthrow the Afghan government. We refer to this situation as the "paradox of the heavy-handed insurgent"insurgents can build public support despite contributing to violence if they can convince civilians that they are the most effective and reliable option for local security.

The paradox of the heavy-handed insurgent depends on four scope conditions. First, the public must have an unmet need for security. This unmet need for security will drive psychological distress that leads individuals to search for a governance alternative. Second, the insurgents must have a reputation for effective governance in communities under their control. Third, civilians will update prior beliefs about insurgents' motives and intentions based on personal past experience with armed groups. Civilians who have suffered past victimization will downgrade their support for insurgent governance. Fourth, insurgents will have an advantage at attracting public support if they come from the same ethnic or sectarian in-group as the as the public in question. In the presence of these scope conditions, insurgents can credibly signal to civilians that they are a better governance alternative than the incumbent regime.

We test the paradox of the heavy-handed insurgent through an analysis of the Asia Foundation's 2018 Survey of the Afghan People. Our results confirm that in governmentcontrolled areas of Afghanistan, the Taliban actually won support from Pashtuns who felt most insecure, even when the Taliban was viewed as the chief cause of that insecurity. The results also show that the Taliban was opposed by those who experienced harm at their hands and those who are not Pashtuns, the dominant ethnic group comprising the Taliban. Thus, the Taliban won "hearts and minds" among Pashtun Afghans primarily by creating insecurity-i.e., the psychological need 
to end the threat to life and limb - by relying on a reputation for bringing order to areas under its control. However, the more Afghans experience past harm at the hands of the Taliban, the more they opposed the group. Thus, the advantage of being a heavy-handed insurgent is limited by the effects of civilian victimization, as well as the presence of a viable alternatives for security.

Our argument proceeds in six parts. In the next section, we examine existing explanations of civilian support for armed groups in fragile states. Next, we examine the empirical setting of the Afghan conflict by examining descriptive statistics from the 2018 wave of The Survey of the Afghan People. After that, we advance a novel theory of civilian support based on the paradox of the heavy-handed insurgent. In the penultimate section, we test our argument and predictions about Pashtun support for the Taliban. We conclude by summarizing our findings, exploring policy implications, and discussing opportunities for future research.

\section{Afghan Public Opinion and Public Support for Taliban}

Despite nearly two decades and \$2 trillion USD in economic investment, humanitarian assistance, and counterinsurgency operations, most Afghan civilians confronted a perpetual state of physical and economic insecurity between October 2001 and August 2021. Civilians' lack of reliable access to basic needs is well documented in multiple waves of public opinion data collected over the last twenty years by The Asia Foundation's biannual Survey of the Afghan People. Our analysis focuses on the 2018 wave of the survey, enumerated by the Afghan Center for Socio-Economic and Opinion Research (ASCOR) in July 2018.

First, it is instructive to explore what the Afghan population was primarily concerned about in the summer of 2018. The increasingly grave security situation was reflected in how the Afghan public thought about the direction of the country. Respondents were asked: "Overall, based on 
your own experience, do you think things in Afghanistan today are going in the right direction, or do you think they are going in the wrong direction?" Sixty-one percent of the respondents answered that the country was moving in the wrong direction, 33 percent said the country was moving in the right direction, and 6 percent did not know. Consider that in 2013, 58 percent of Afghans said the country was moving in the right direction and just 37 percent said it was moving in the wrong direction. When asked what their top two reasons for why they said the country was moving in the wrong direction, 73 percent of respondents in 2018 said it was because of the security situation, 38 percent said it was because of the economy, and 33 percent said because of governance in the country.

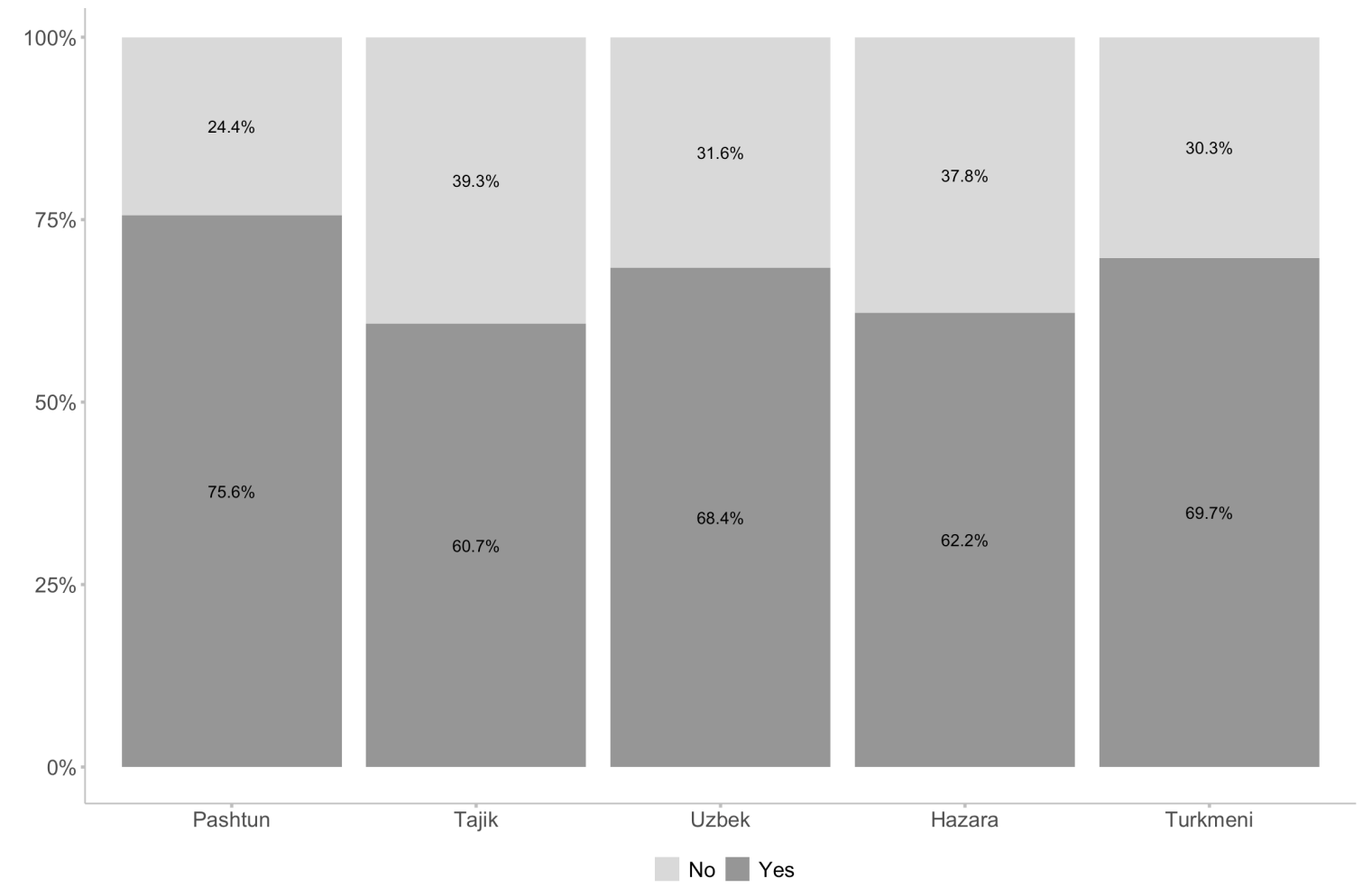

Figure 1: Do you fear for your own personal safety or security or for that of your family these days?

Another piece of evidence that the insurgency and the break down in governance was having a negative impact on the psychology of the population can be found in how much fear for 
personal safety there was in Afghanistan in 2018. Figure 1 shows the averages of the major ethnic groups of Afghans who said they feared for their personal safety. As is clear in the graph, Pashtuns were most concerned about their personal security in 2018. This is logical given that most of the fighting between the Taliban and the Afghan security forces took place in Pashtun-majority areas, such as Helmand, Kandahar, Patika, and Nangarhar provinces.

Figure 2 shows the distribution of respondents in the four major ethnic groups of Afghanistan who reported in 2018 that they or their family members had been the victims of violence, the vast majority of which the respondents attributed to Taliban insurgents.

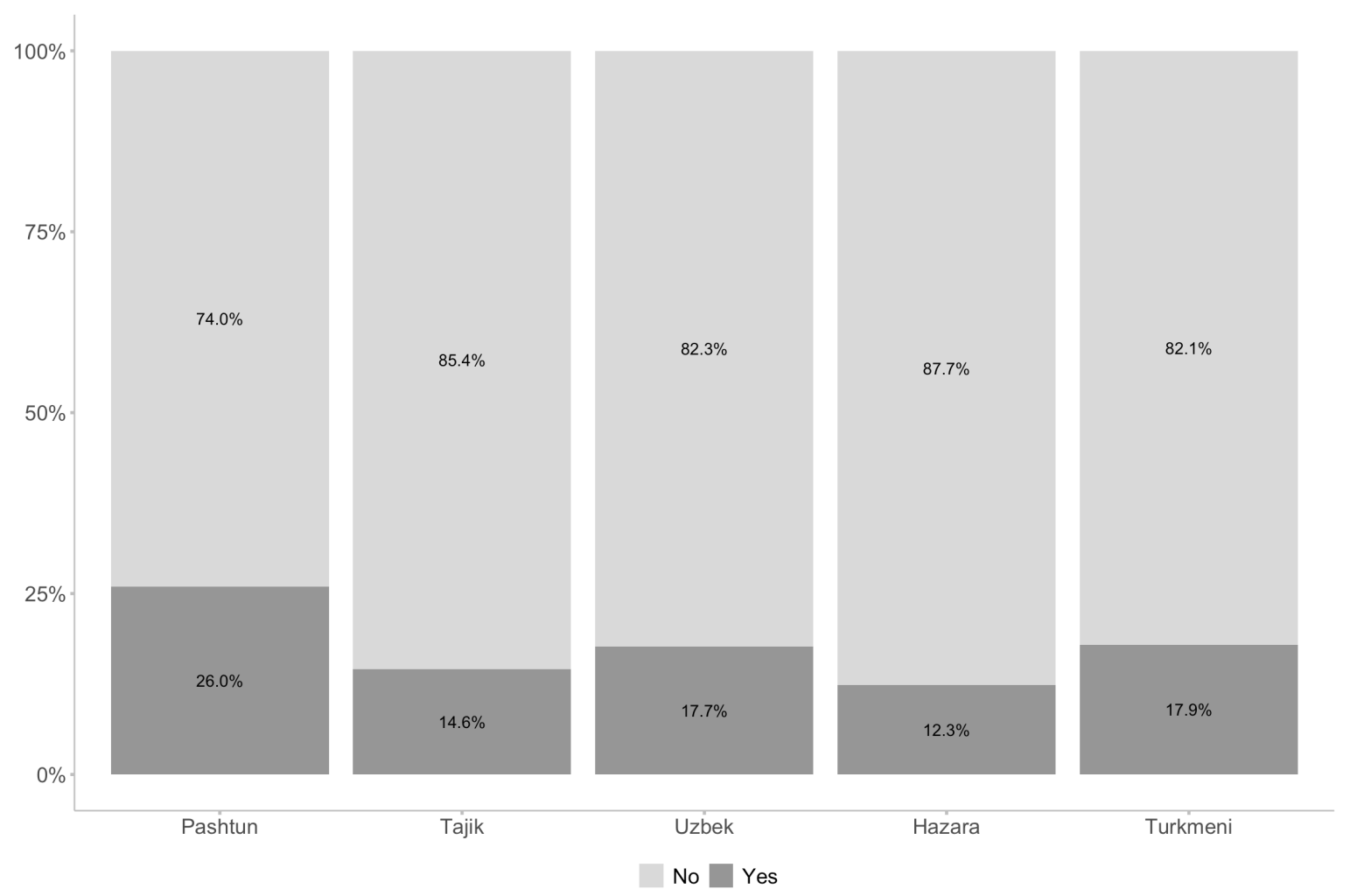

Figure 2: Have you or has anyone in your family suffered from violence or some criminal act in the past year?

As is clear in the figure, the Pashtun population in Afghanistan reported a much higher incidence of being victims of violence compared to other ethnic groups. More than a quarter of 
the Pashtun population said that they or their family had been victims of Taliban violence. This is a nearly nine percentage point higher rate of reporting victimization by violence compared to Uzbeks, who were the ethnic group that experienced the second-highest incidence of violence.

Does this deeper sense of insecurity among Pashtuns in the summer of 2018 mean that they had less sympathy for Taliban insurgents? Figure 3 shows the level of sympathy expressed for the Taliban among the four major ethnic groups of Afghanistan, among the subset of respondents who fear for their safety and have suffered past victimization during the conflict. This subset represents 15 percent $(1,785$ respondents $)$ of the total respondents from the 2018 survey wave $(n=12,303)$.

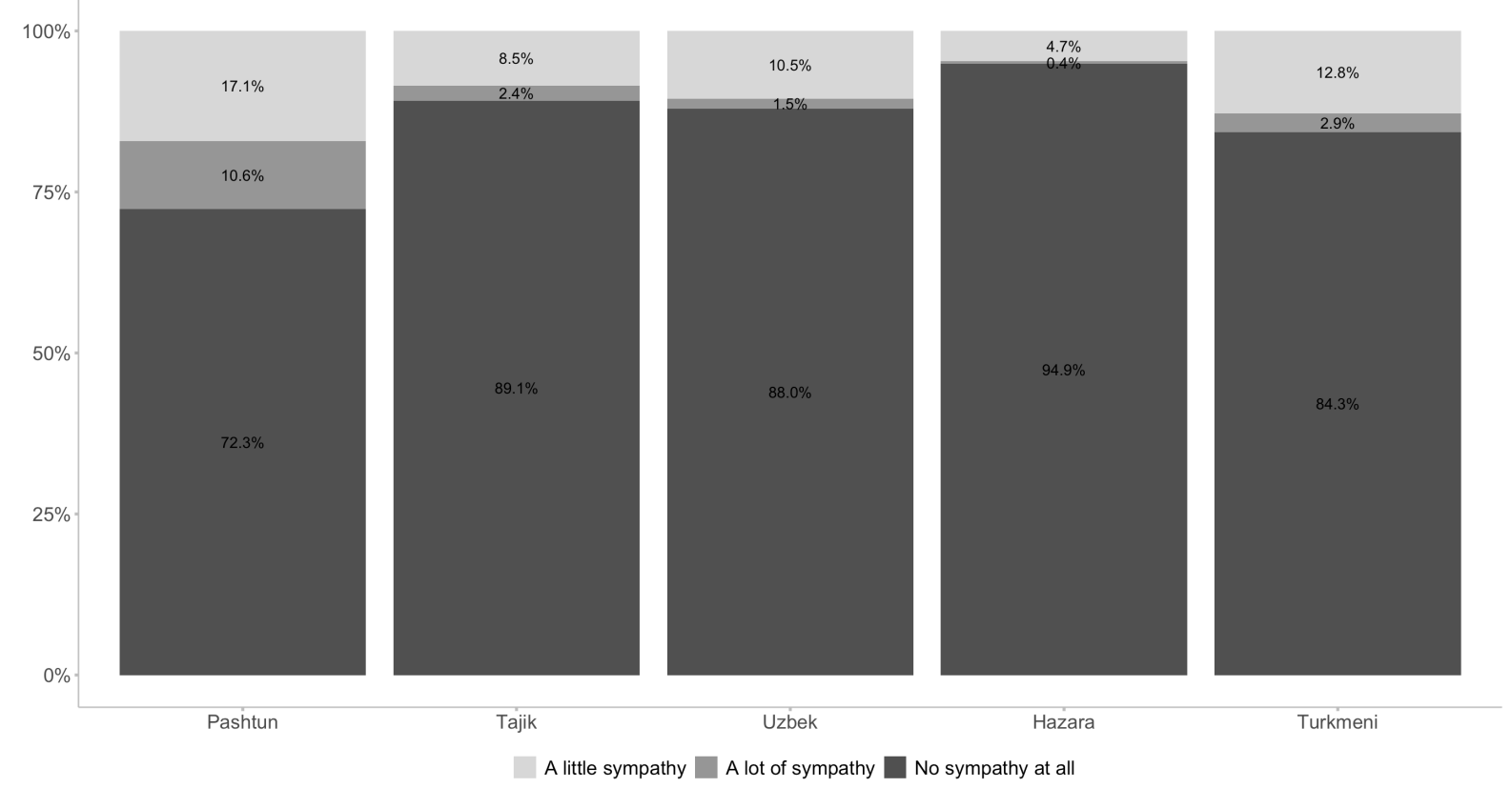

Figure 3: Thinking about the reasons why the Taliban have been fighting during the past year, in general, would you say that you have a lot of sympathy, a little sympathy or no sympathy at all for the Taliban?

Clearly there is a large difference between how the major ethnic groups view the Taliban. While most Pashtuns (72 percent) said that they did not have sympathy for the insurgent group, 27 percent said that they did have sympathy for the group. Compare this to the Uzbeks, the ethnic group with the second highest level of sympathy toward the Taliban with 12 percent indicating 
such an attitude. Pashtuns are nearly three times as likely to be sympathetic to the Taliban as the next most sympathetic ethnic group, the Uzbeks. This indicates a clear coethnic bias in how Afghans view the Taliban and it is not surprising given the overwhelmingly Pashtun dominance in the Taliban movement. The Taliban is made up mostly of Pashtuns, is led almost solely by Pashtuns, and operated primarily in the Pashtun areas of Afghanistan before its dramatic breakout in the summer of 2021.

This pattern of public opinion highlights an important question for those trying to understand the determinants of public support for insurgency in Afghanistan and other fragile states. What drove nearly 28 percent of Afghan Pashtuns surveyed in 2018 to say that they had sympathy for the Taliban, despite the fact that their insurgency was driving insecurity in the country and the Taliban's checkered record of governing the country in the past? Why are those Pashtuns - the key disputed population in Afghanistan-willing to throw their lot in with the insurgents? In the next section, we examine existing arguments for civilian support during wartime and advance a novel explain for public support for heavy-handed insurgents.

\section{Existing Explanations for Civilian Support During Wartime}

For civilians in contested communities, popular support often reduces to a decision about the "best worst" option for governance among available security providers. Rather than confronting a dichotomous choice between collaboration and resistance, however, noncombatants often have a menu of strategies for engaging local combatants. Individuals may support the counterinsurgents, lean toward the counterinsurgents, be undecided/dislike both counterinsurgents and insurgents (and organize to defend themselves), lean toward insurgents, or support insurgents. ${ }^{4}$ Others might choose to flee their communities, hide or lie low, or "sit on the fence" in order to determine which 
armed group has the upper hand. ${ }^{5}$ The stakes for building public support are high, because in asymmetric conflicts the civilian population serves as a force multiplier - they can provide recruits, safe haven, material resources, and crucial intelligence about adversaries' goals, strategies, and capabilities. While in-group favoritism-along ethnicity, sect, or classundoubtably shapes how civilians perceive the motives and intentions of armed actors, a reputation for reliable and effective governance is the most important factor in building civilian support. ${ }^{6}$

Insurgents recognize civilians' incentives to sit on the fence as the conflict evolves. As such, armed groups will often tailor their goals and tactics in order to induce the weak acquiescence or passive toleration of the civilian population. Insurgents' reliance on indiscriminate violence, targeting public infrastructure, and resource extraction/taxation, provide recent examples. ${ }^{7}$ Counterinsurgents also recognize insurgents' incentives to leverage violence in order to induce public support. In response, counterinsurgency theory and practice has emphasized the need for pro-regime forces to win local "hearts and minds" through effective and reliable public goods and services provision. The concept of "take, hold, and build" is based on the idea that counterinsurgents must first establish security (take and hold) and then build the conditions and infrastructure for economic development and prosperity. ${ }^{8}$ A "population-centric" approach to counterinsurgency warfare (COIN) is now the conventional wisdom among theorists and practitioners alike, despite its mixed record in restoring governance in fragile states. ${ }^{9}$

Since the onset of the US wars in Afghanistan and Iraq, scholars have examined the assumption that hearts and minds can be won (or bought) through effective governance. Berman, Felter, and Shapiro found that economic service provision in Iraq reduced insurgent violence. ${ }^{10}$ The logic behind the drop in violence was that insurgents would have less room to operate in an environment where the public was less hospitable to them because the public's economic needs 
were being met. Similar studies conducted in Iraq and Afghanistan have also found that economic development and economic service provision helps to turn civilians against insurgents. ${ }^{11}$ Lyall, Zhou, and Imai found in a 2019 study that perceived effort to help civilians economically mattered more than actual success at creating jobs and boosting incomes in affecting civilian attitudes toward the government. ${ }^{12}$ Thus, the perception that the government is trying to improve lives through provision of economic goods and services is crucial to building legitimacy among civilians for the incumbent regime.

Stollenwerk found that as perceptions of security improved in Afghanistan, it increased the legitimacy of the International Stabilization and Assistance Force (ISAF) in eyes of the Afghan public in its areas of operations. ${ }^{13}$ Mikulashek, Pant, and Tesfaye found that the expectation that the incoming Iraqi government would provide security to be an important factor in rising support for the government and declining support for insurgents. ${ }^{14}$ Böhnke, Koehler, and Zürcher found in a longitudinal study in Afghanistan running from 2007-2015, that the provision of security was a key condition in non-combatants decision to attach their loyalty to the state. ${ }^{15}$ Beth, Christia, and Enikolopov demonstrated in a study of the factors that drove support for the Afghan government that providing security to the population was a precondition for attracting support from the population. ${ }^{16}$ Only when Afghan civilians felt secure did they then care about economic service provision. Hanania found that in the period between 2009 and 2014 in Afghanistan, the Taliban, which was not strong enough to take and hold territory on its own, would seek to disrupt the impression that the Afghan government could keep security in areas it controlled. ${ }^{17}$ The point of these efforts to disrupt security was to undermine public confidence in the Afghan government, rather than capture new territory or mobilize new recruits. 
Scholars have also found that public perceptions of governance derive from how combatants treat the civilian population. Several recent studies show that causing physical harm to civilians leads them to view the perceived source of the harm more negatively and raise support for the other side. ${ }^{18}$ Condra and Shapiro showed that both sides in the Sunni insurgency in Iraq were punished by the public for their harm to civilians. ${ }^{19}$ Condra, Felter, Iyengar, and Shapiro found the same pattern of results in Afghanistan in 2011. ${ }^{20}$ Shaver and Shapiro, in a study of informing in Iraq, showed that informing against insurgents went up when up when insurgents inadvertently killed civilians. By the same token, government harm to civilians led to a decrease in informing on insurgents. ${ }^{21}$

Beyond civilian victimization and indiscriminate violence, however, combatants can also undermine public support through their inability to curb other forms of exploitation, predation, and criminality in areas under their control. In Afghanistan, for example, such criminals can range from petty bandits and robbers to powerful warlords. ${ }^{22}$ Combatants that hold territory (even just nominally) are held responsible by the civilians living in that territory for maintaining security. Studies have shown that the post-Taliban Afghan government did a poor job of extending their power to govern the hinterlands of Pashtun Afghanistan and often ceded security control to warlords who were nominally loyal to the state but used their power and influence to predate on the local population. ${ }^{23}$ In sum, having a reputation for ineffective governance creates strong incentives for civilians to support a more heavy-handed alternative.

Existing work yields important insights into what factors shape civilian support for local combatants. The paradox of why insurgents gain popular support among vulnerable civilians despite their contribution to indiscriminate violence, however, remains understudied. We contend that the key to understanding this paradox is an individual's unmet need for security and an 
insurgent group's reputation for maintaining order in the areas under its control. In the next section, we provide a novel theory of how civilians form preferences for heavy-handed insurgents, despite attributing their past experiences with victimization to opposition forces.

\section{Civilian Support for Heavy-Handed Insurgents}

At the heart of civilian support lies perceptions about the likelihood that combatant governance will allow individuals to meet their basic needs. Individuals form and update beliefs based on the information available to them about armed groups' behavior in the community. Public assessments of combatants' resolve and capacity are based on subjective perceptions, and as such are subject to a litany of cognitive biases, especially motivated reasoning. All else equal, individuals are more likely to support combatants that they believe can help meet their basic needs, even if those combatants are responsible for indiscriminate violence in the community. Just as unmet basic needs are insufficient to determine how one thinks about armed groups, information about the group is also indeterminate in shaping civilian beliefs, attitudes, and behaviors.

We argue that three core basic needs motivate civilian support for insurgent governance: safety, sustenance, and significance (the " $3 \mathrm{~S}$ 's"). The need for security refers to an individual's desire to be free from physical harm. The need for sustenance refers to an individual's desire to have food, shelter, health, or other things that make life sustainable and comfortable. The need for significance refers to the desire to feel like one's life matters, one has control over one's life, and

that one is respected. ${ }^{24}$ While other basic needs inform civilian preferences, combatants have the strongest direct impact on civilians' basic needs for safety, sustenance, and significance.

Individuals will experience psychological distress when basic needs are left unmet, when or combatants pose a direct threat to meeting those needs on a regular basis. While distress has 
psychological manifestations, it is the psychological impact of distress that motivates behavior. Specifically, the prospect of not having one's needs met for safety, sustenance, and significance produces anxiety, anger, and depression. In order to avoid this psychological distress, individuals will look for opportunities to reduce the likelihood of safety, sustenance, and significance loss by supporting combatants that can protect and provide for those needs. ${ }^{25}$

Individuals assess combatants' ability and willingness to provide for basic needs based on how they access and process information. When encountering armed groups operating in the community, individuals subconsciously ask: what was my first-hand experience with this group? Did they provide us with security, food and shelter, or a sense of significance? Or did they create a greater need for those things? If combatants created greater needs for sustenance and significance, they will be judged negatively. But if combatants actually did physical harm to the individual or his/her family in the past, they will be viewed as a very important threat. As stated above, when security needs become acute, they will predominate in the thinking of those who face them, pushing sustenance and significance needs into a position of lesser consideration. The scenario that is most likely to lead to sympathy toward insurgents is when an individual has unmet basic needs and has trustworthy information that shapes their belief that insurgents will be able to provide for those needs.

Civilians acquire information about combatants' willingness and capacity to provide for basic needs through various channels. Information from social networks serves as one primary source. Friends, family, and other trusted others can convey information about insurgents that will be more likely to be believed that if comes from an untrusted source. Another source of information is past experience with armed groups. Personal encounters - either positive or negative- provides a baseline by which individuals shape their future expectations. With each subsequent encounter 
with armed groups, individuals update their beliefs about the likelihood of basic needs provision. Negative past experiences (either personal or third-hand) - especially previous victimization, exploitation or selective violence-is most salient for shaping expectations about combatants' future behavior.

Civilians also use social identity as a heuristic for updating beliefs about combatants' ability and willingness to provide for basic needs. ${ }^{26}$ Shared social identity — especially ethnicity, sect, or class - is a very important cue for expectations about how one will be treated or perceived. ${ }^{27}$ Individuals are more likely to believe that combatants from the same in-group are more likely to help them because of social identity bias. This means that people have a tendency to think more positively about their in-group than out-groups. There are several factors that can drive in-group bias, but it is a crucial human survival mechanism because people are more likely to survive and thrive if they cooperate as a group rather than try to meet basic needs on their own. Thus, combatants from one's in-group will be more easily trusted to meet the members of the ingroup's needs than combatants from an out-group.

The context one finds oneself in will determine which of the basic needs will most motivate behavior. In situations where safety concerns are acute, security needs will be the primary motivator for behavior. This is because of the innate human drive to survive and avoid physical harm. While some individuals may disregard perceived unmet security needs, this is not typical as human instinct pushes survival and harm avoidance when those things are pressing. Thus, in an environment where insurgents and counterinsurgents are actively fighting, or there is a breakdown in security and criminals are predating on the population, it is very likely that security needs will be the prime motivators of actions taken by noncombatants. Individuals with unmet security needs may try to flee the area, back the insurgents, back the counterinsurgents, or back some other non- 
state actor that can provide security. Individuals with unmet security needs will likely sympathize with the force that is perceived most likely to meet their pressing need for security, regardless of whether they contribute to increased indiscriminate violence.

Insurgents with a reputation for restoring security in vulnerable communities-i.e., "heavy-handed" insurgents — will have a sympathy advantage over alternative security providers who are viewed as less competent or willing to provide order. This can be a paradoxical situation for the heavy-handed insurgents because they may have actually caused the insecurity problem by wearing down the governing authorities who can no longer muster the forces to keep security in the area. Governing authorities may face morale problems, defections, desertions, or battlefield attrition due to insurgent operations. Thus, it may be the insurgents who are creating the conditions for insecurity but if they can also be viewed as capable of restoring security, people desperate for security will not care who is actually the root cause of the insecurity but will want security restored as soon as possible. The only exception holds for armed groups who have been responsible for past acts of victimization, exploitation, or predation. If civilians directly attribute threats to basic needs to specific combatants, even expectations of restored order will be insufficient for generating public support. The promise of order absent the guarantee of no harm fails to meet an unmet need for security, but rather threatens greater insecurity.

What does the logic of the heavy-handed insurgent tell us about which Afghan civilians are most likely to sympathize with the Taliban? Among Afghan Pashtuns - the population that will be explored in this analysis - those who had acute needs for security were the most likely to sympathize with the Taliban because the government of Afghanistan was unable to maintain security. Among Pashtuns, the Taliban had a reputation for establishing order in areas where they governed, with exceptions noted below. This leads to the following hypothesis: 
$\mathrm{H}_{1}$ : The more an Afghan Pashtun is concerned about his/her security, the more likely s/he is to sympathize with the Taliban.

However, not all Pashtun communities would welcome the Taliban as guardians of their security, even though they might have shared a common in-group and have unmet needs for safety. In particular, those Pashtuns who attributed their past victimization (personal or otherwise) to Taliban insurgents would be less likely to support future governance by the Taliban. Thus, as expected from much of the literature on civilian victimization and popular support, those who have experienced harm from the Taliban would be less likely to be sympathetic to them in the future. This modification to the logic of the heavy-handed insurgent is expressed in the following hypothesis:

$\mathrm{H}_{2}$ : Afghan Pashtuns who attribute past victimization to insurgents are less likely to support future governance by the Taliban.

In the following section, we test these hypotheses with public opinion data from the 2018 Survey of the Afghan People.

\section{Research Design and Methods}

We evaluate the key predictions of the "paradox of the heavy-handed insurgent" by analyzing public opinion data from the 2018 wave of the Survey of the Afghan People. This survey was commissioned by the Asia Society and fielded by ASCOR, an Afghan polling organization. The survey employs national proportional stratified probability sampling techniques. The survey was only carried out in areas not in direct armed conflict or Taliban control to ensure the safety of the 
enumerators and the respondents. In order to gain representative responses, women enumerators interviewed women and men interviewed men. The interviews were done face-to-face and used no written cards for respondents, given the high rate of illiteracy in Afghanistan. They were also administered in the many languages of Afghanistan in order to elicit a representative sample of responses. Unlike some other surveys of Afghans, the ASCOR survey accurately reflects the urban-rural breakdown of Afghan society. It does not have an urban bias, as is common in some surveys fielded in difficult survey conditions. Table 1 provides an overview of the descriptive statistics of the sample.

Table 1: Respondent Descriptive Statistics

\begin{tabular}{lll}
\hline Covariate & $\begin{array}{l}\text { Full Sample } \\
(\mathrm{n}=12,303)\end{array}$ & $\begin{array}{l}\text { Pashtun subsample } \\
(\mathrm{n}=4,203)\end{array}$ \\
\hline Gender & $5,951(48 \%)$ & $1,873(45 \%)$ \\
Female & $6,352(52 \%)$ & $2,330(55 \%)$ \\
Male & & \\
Age Group & $5,558(45 \%)$ & $1,932(46 \%)$ \\
$<30$ & $4,904(40 \%)$ & $1,846(44 \%)$ \\
$31-50$ & $1,453(12 \%)$ & $352(8.4 \%)$ \\
$51-65$ & $388(3.2 \%)$ & $73(1.7 \%)$ \\
$65<$ & & \\
Ethnicity & & $0(0 \%)$ \\
Hazara & $1,476(12 \%)$ & $4,203(100 \%)$ \\
Pashtun & $4,203(34 \%)$ & $0(0 \%)$ \\
Tajik & $4,282(35 \%)$ & $0(0 \%)$ \\
Turkmen & $1,266(10 \%)$ & $0(0 \%)$ \\
Uzbek & $1,076(8.7 \%)$ &
\end{tabular}

Education 


\begin{tabular}{lll}
\hline Covariate & $\begin{array}{l}\text { Full Sample } \\
(\mathrm{n}=12,303)\end{array}$ & $\begin{array}{l}\text { Pashtun subsample } \\
(\mathrm{n}=4,203)\end{array}$ \\
\hline 1-6 years of formal education & $2,074(17 \%)$ & $900(21 \%)$ \\
10-12years of formal education & $2,783(23 \%)$ & $884(21 \%)$ \\
12+ years of formal education & $392(3.2 \%)$ & $126(3.0 \%)$ \\
7-9 years of formal education & $875(7.1 \%)$ & $338(8.0 \%)$ \\
No formal education & $6,179(50 \%)$ & $1,955(47 \%)$ \\
Percent Employed & & \\
Employed & $5,974(49 \%)$ & $2,186(52 \%)$ \\
Unemployed & $6,329(51 \%)$ & $2,017(48 \%)$ \\
Income Level & & \\
$10,001-15,000$ Afs & $2,127(17 \%)$ & $897(21 \%)$ \\
$15,001-20,000$ Afs & $1,106(9.0 \%)$ & $502(12 \%)$ \\
$2,001-3,000$ Afs & $821(6.7 \%)$ & $172(4.1 \%)$ \\
$20,001-25,000$ Afs & $310(2.5 \%)$ & $176(4.2 \%)$ \\
$25,001-40,000$ Afs & $294(2.4 \%)$ & $160(3.8 \%)$ \\
$3,001-5,000$ Afs & $2,262(18 \%)$ & $584(14 \%)$ \\
$5,001-10,000$ Afs & $4,487(36 \%)$ & $1,498(36 \%)$ \\
Less than 2,000 Afs & $716(5.8 \%)$ & $143(3.4 \%)$ \\
More than 40,000 Afs & $180(1.5 \%)$ & $71(1.7 \%)$ \\
\hline & & \\
\hline
\end{tabular}

The analysis uses a sample of 4,203 adult Pashtun respondents. We model Afghan support for the Taliban using an ordered probit regression model, because the dependent variable is an ordinal variable with more than two and less than five response categories. While these models are not causally identified (due to selection on observables), they do provide reliable associations for the relationship between public sympathy for the Taliban and the unmet need for security among Pashtun civilians. ${ }^{28}$ 
To determine the relative predictive power of the explanatory variables, we calculate the marginal effects of those variables. We do so by calculating the first difference- - the change in the probability of a respondent showing sympathy for the Taliban when the variable of interest is changed from its minimum to its maximum value — while the other independent variables are held constant at their means. We do this for each of the predictive variables in our model. Calculating the marginal effects in this away allows us to determine the magnitude of the impacts of the independent variables upon the dependent variable.

\section{The Model}

We operationalize the core concepts of our theory using existing measures found in the 2018 Survey of the Afghan People. While some of these measures may be less than ideal for a study of sympathy toward the Taliban, they are the best publicly available Afghan public opinion data for

testing the hypotheses that motivate this research. Given the tremendous obstacles to doing opinion research in an increasingly insecure Afghanistan, these data are more useful than anything that could be gathered over the course of the conflict.

\section{Dependent Variable}

The dependent variable in the analysis - sympathy for the Taliban - is operationalized with the following survey question: Thinking about the reasons why the Taliban have been fighting during the past year, in general, would you say that you have a lot of sympathy, a little sympathy or no sympathy at all for the Taliban? In the Pashtun subsample, 27.1 percent of respondents had some measure of sympathy for the Taliban (15.3 percent registered support in the full sample). Table 2 provides a cross-tabulation of Taliban support by the full sample and Pashtun subsample. 
Table 2: "Thinking about the reasons why the Taliban have been fighting during the past year, in general, would you say that you have a lot of sympathy, a little sympathy or no sympathy at all for the Taliban?"

\begin{tabular}{|l|cc|}
\hline & $\begin{array}{c}\text { Full Sample } \\
(\mathrm{n}=12,303)\end{array}$ & $\begin{array}{c}\text { Pashtun Subsample } \\
(\mathrm{n}=4,203)\end{array}$ \\
\hline A lot of sympathy & $4.8 \%(590)$ & $11.3 \%(464)$ \\
A little sympathy & $10.5 \%(1,287)$ & $15.8 \%(665)$ \\
No sympathy at all & $84.7 \%(10,426)$ & $73.1 \%(3,074)$ \\
\hline
\end{tabular}

Independent Variables

Our theory argues that an insurgent group's perceived ability to provide security will make civilians more likely to sympathize with insurgents. As argued above, the Pashtuns most likely to sympathize with the Taliban are those who are most concerned about their security. There are two measures in the Survey of the Afghan People that are useful for operationalizing respondents' unmet need for security. First, there is a question that captures the respondent's perception of her/his security. The question asks: How often do you fear for your personal safety or for that of your family these days? Would you say always, often, sometimes, rarely or never fear for you and your family's safety? Figure 4 shows the distribution of responses to this question among all Afghans in 2018. 


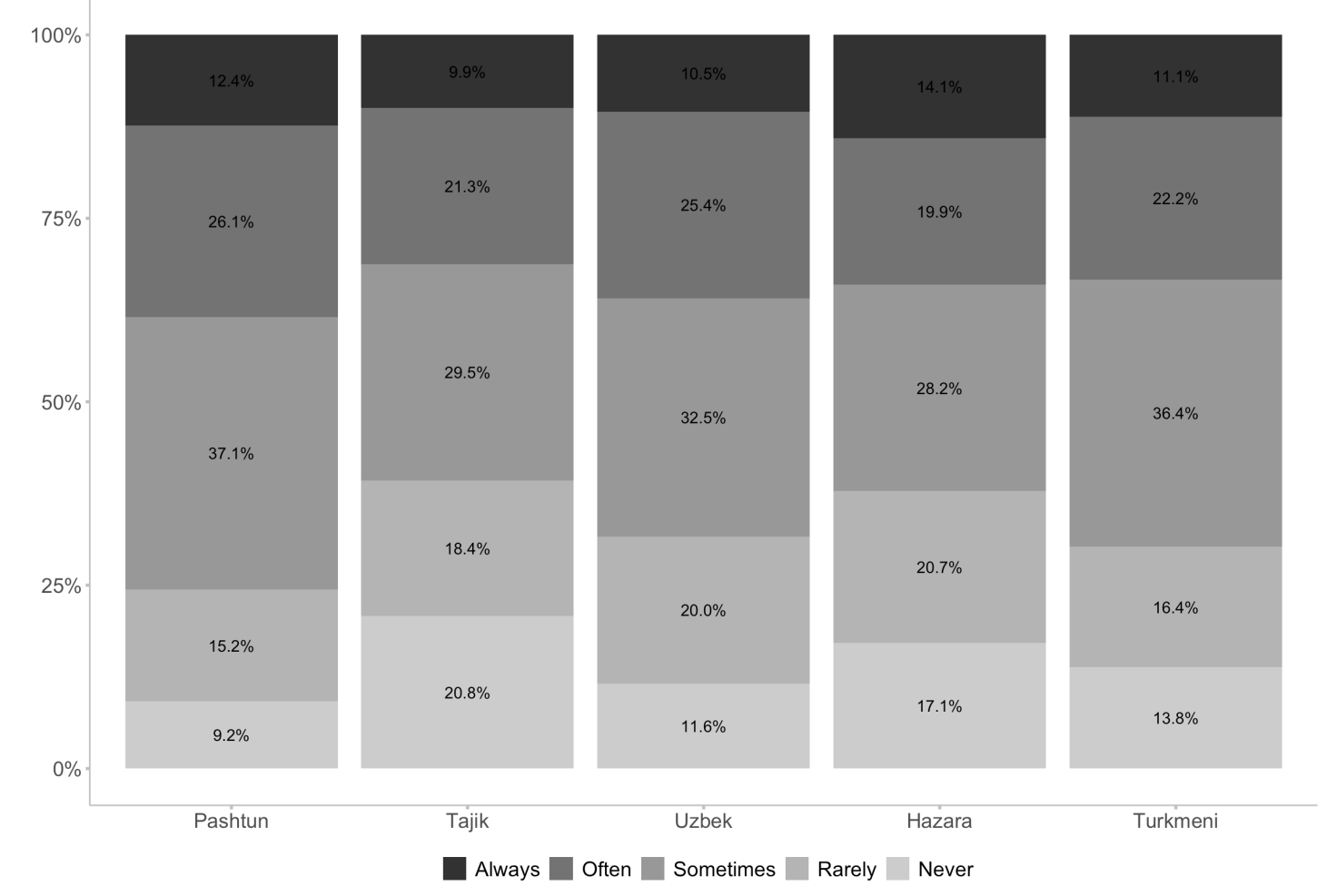

Figure 4: How often do you fear for your personal safety or for that of your family these days?

Our second variable operationalizing respondents' unmet need for security comes from whether respondents have been a victim of past violence: Have you or has anyone in your family suffered from violence or of some criminal act in the past year? The response categories are: yes and no. It is very important to note that the overwhelming majority of those who answered yes to this question were victims of the Taliban (70 percent) as opposed to Coalition or Afghan security forces. Figure 2 above displays the distribution of Afghans who say they have been victims of violence. Importantly, 26 percent of Pashtun respondents recorded that they have been affected by insurgent violence despite belonging to a common ethnic in-group with the Taliban. This evidence suggests that Pashtun civilians are more likely to fear indiscriminate violence due to competition between armed groups rather than selective targeting or victimization by Taliban insurgents. 


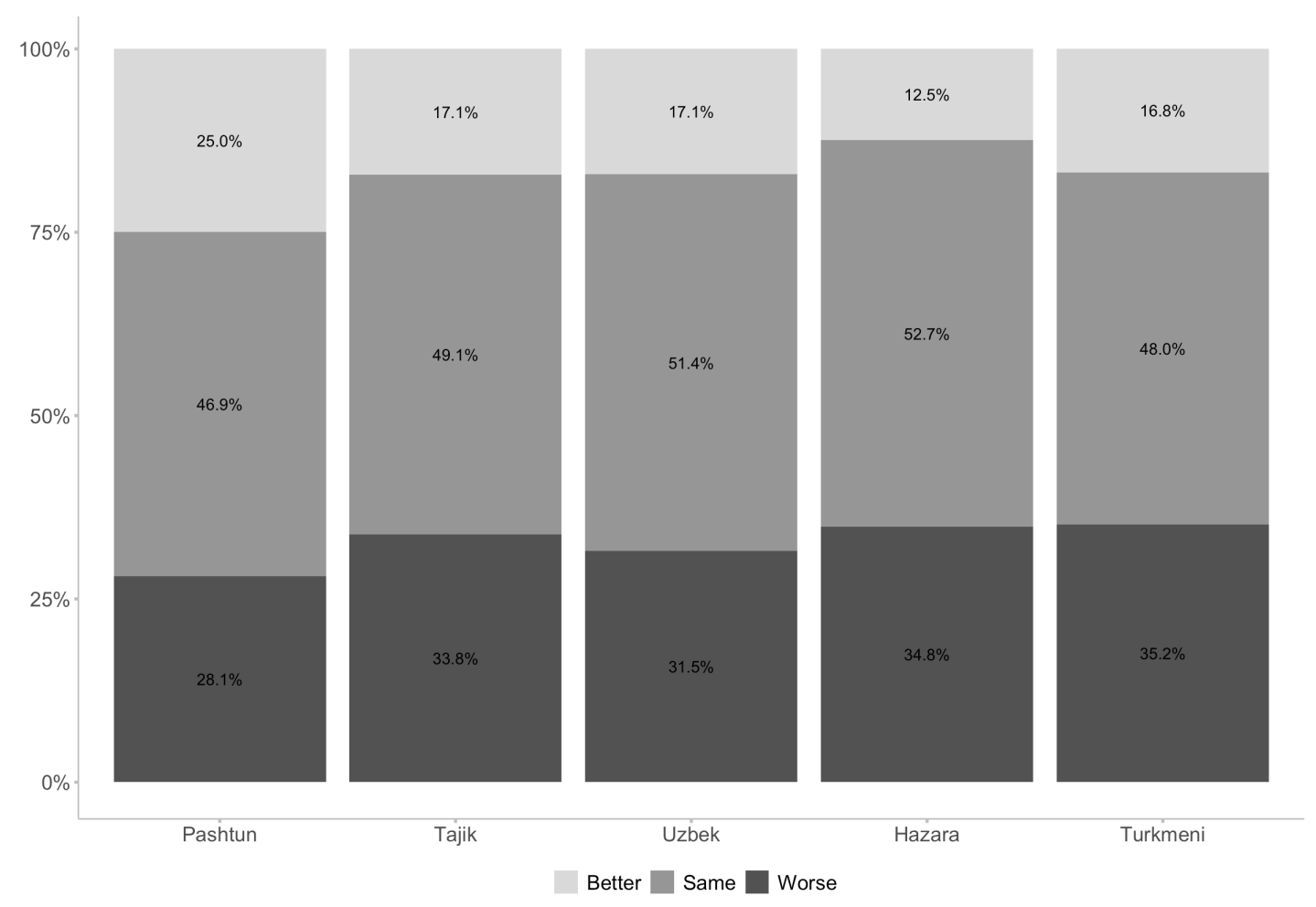

Figure 5: Compared to one year ago, would you say that the financial situation of your household has gotten better, remained the same, or gotten worse?

Another current trend in theorizing about civilian sympathy for insurgents is that the government's perceived inability or unwillingness to provide basic public goods and services will make civilians more likely to sympathize with insurgents. In the survey, the set of questions that best operationalize these concepts asks: Compared to one year ago, would you say that the situation for your household has gotten better, remained the same, or gotten worse with respect to the following? There are eleven issues that a respondent is asked to assess in terms of how she or he thinks have better or worse over the last year. We selected the question that asks about the financial situation of your household. Figure 5 shows the distribution of responses to the question about household finances among Afghans in 2018. In comparison to security-related questions, there were few differences across respondent ethnicity with respect to one's financial situation. 
Across each ethnic group, approximately 70 percent said their financial situation was the same or better, and the remaining 30 percent said their situation has become worse.

Our analysis also includes a series of control variables. First, we condition for whether respondents reside in an urban or rural community, including accounting for district-level effects. In rural districts across Afghanistan, civilian communities confront higher levels of insurgent violence and have fewer alternatives for security provision. Second, we include a series of variables to condition for respondents' demographic characteristics, including gender, age, education and income.

\section{Results and Discussion}

We begin our analysis by reporting the results from a model of all Afghan respondents (n $=12,303)$. The results of the ordered probit analysis are found in Table 3. A coefficient plot with 95 percent confidence intervals is found in Figure 6.

Table 3: Ordered Probit Model (Full Sample)

Dependent Variable: Sympathy for the Taliban

$\begin{array}{lll}\text { Independent Variables } & \text { Coefficient (SE) } & \text { First Difference } \\ & & \\ \text { Rural resident } & 0.232(0.040)^{* * *} & .020 \\ \text { District } & -0.000(0.000)^{*} & .012 \\ \text { Better finances } & 0.070(0.020)^{* * *} & .014 \\ \text { Fear for security } & 0.097(0.012)^{* * *} & .040 \\ \text { Family victim } & -0.221(0.033)^{* * *} & .027 \\ & & \\ \text { Gender } & -0.244(0.031)^{* * *} & .020 \\ \text { Age } & 0.001(0.001) & \\ \text { Education } & 0.016(0.012) & \\ \text { Income } & -0.000(0.000)^{*} & .050 \\ \text { Pashtun dummy } & -0.442(0.048)^{* * *} & .061\end{array}$




$\begin{array}{lll}\text { Tajik dummy } & 0.200(0.051)^{* * *} & .040 \\ \text { Uzbek dummy } & 0.214(0.067)^{* * *} & .020 \\ \text { Hazara dummy } & 0.716(0.075)^{*} & .020 \\ & & \\ \text { Cut 1 } & -1.271(0.104)^{*} & \\ \text { N } & 12,303 \\ \text { Log Likelihood } & -5888.758 & \\ \text { Prob }>\text { chi2 } & .000\end{array}$

Note: Figures are unstandardized coefficients shown alongside standard errors. ${ }^{*} \mathrm{p}<.1 ; * * \mathrm{p}<.05 ; * * * \mathrm{p}<.01$ (two-tailed). Cut 1 refers to a "cutpoint" on a standardized normal distribution. Cut points are used to calculate the predicted probabilities for each category of the dependent variable. The constant of the model would be interpreted as the inverse of Cut $1(-1.271)$.

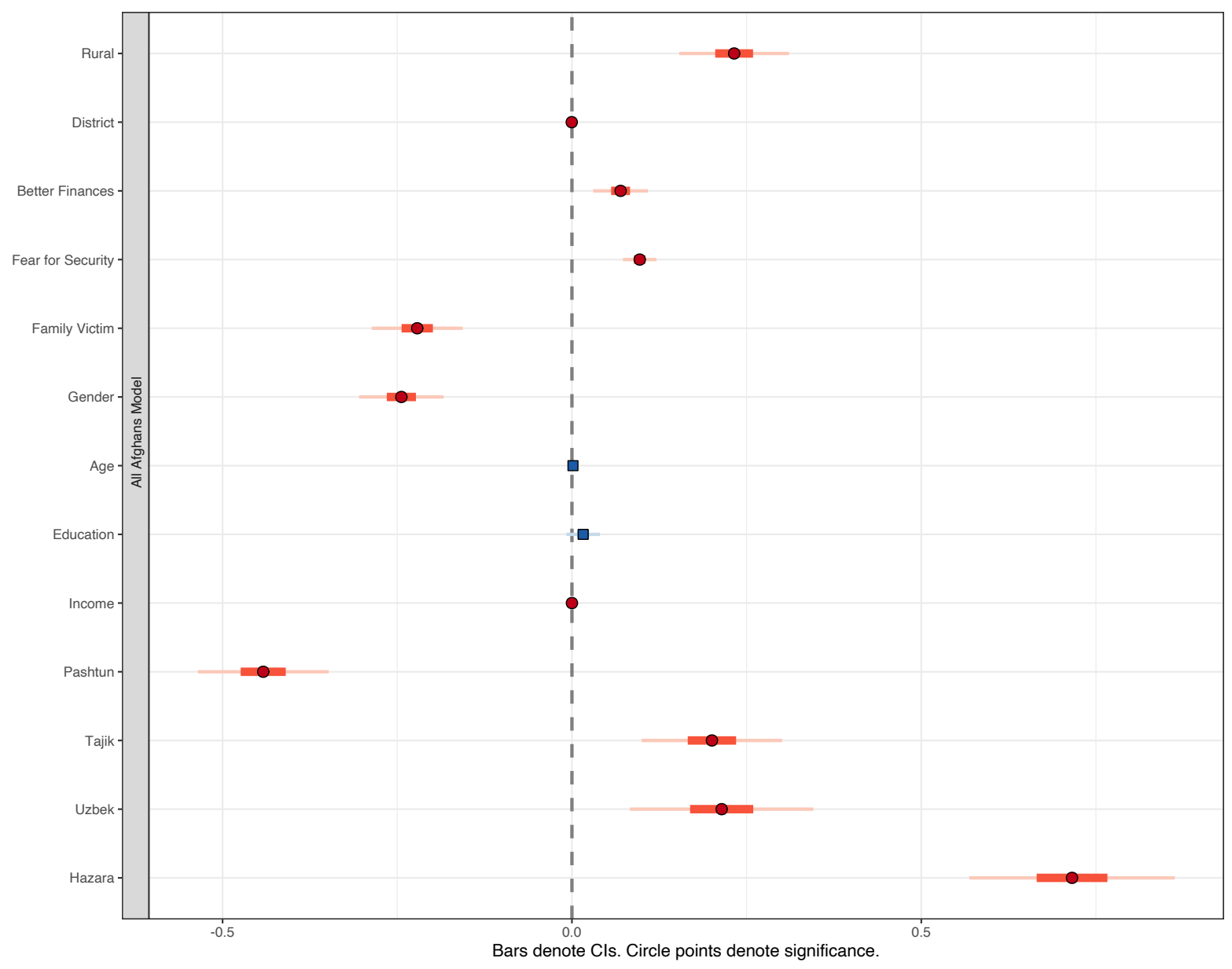

Figure 6: Coefficient Plot for All Afghans Model 
We discuss the results for the independent variables in the order as they are presented in Table 3. For the sustenance variables, assessments of household finances and education proved significant predictors. Both of those variables did not behave as predicted, with those Afghans who believed that their household finances and their access to education worsened over the past year were less likely to be sympathetic to the Taliban. This result seems to show that Afghans are not counting on the Taliban to improve their economic fortunes or access to education.

The two measures of security concerns were both highly significant predictors of sympathy for the Taliban. Those who had experienced violence or had family who had experienced violence were less likely to be sympathetic to the Taliban. This result is consistent with our prediction. Also, following our prediction was that those who feared often for the security of their area were more likely to be sympathetic to the Taliban. Thus, the government's inability to create a sense of security fueled sympathy for the Taliban and the Taliban's law and order image helped its support among the Afghan public.

Among the control variables, rural status was a significant predictor and showed that rural Afghans are more likely to be sympathetic to the Taliban compared to urban Afghans. The same is true of the district control variable. Pashtun ethnicity was a very significant predictor of sympathy for the Taliban, while the three other major ethnicities (Hazara, Tajik, and Uzbek) are all highly significant predictors of being unsympathetic to the Taliban.

Of the demographic control variables, gender and income were significant. Women are less likely to be sympathetic to the Taliban than men at a high level of significance. This is not surprising given the Taliban's record on the treatment of women in Afghanistan. Interestingly, higher income Afghans were significantly more likely to be sympathetic toward the Taliban compared to lower income Afghans. Perhaps, higher income Afghans were more likely to view 
the Taliban as a source of security and stability compared to the government of the Islamic Republic.

To determine the relative predictive power of the explanatory variables, we calculate the marginal effects each variable. We calculate the first differences, or the change in the probability of a respondent giving a positive assessment of the Taliban when the variable of interest is changed from its minimum to its maximum value, while the other independent variables are held constant at their means. We do this for each of the predictive variables in our model. Calculating the marginal effects in this away allows us to determine the magnitude of the impacts of the independent variables upon the dependent variable.

The first differences estimation results reveal that being a Pashtun is, far and away, the most predictive variable of being sympathetic to the Taliban. Thus, being a Pashtun is the most powerful category of explanatory variable in the model, with a first difference value of .061. The next most predictive explanatory variable of sympathy toward the Taliban is those who fear for their security. The first difference value for this variable is .040. The control variable for income was also a very powerful predictor of sympathy for the Taliban, with a first difference value of .050. Also, being a rural Afghan proved somewhat less predictive of Taliban sympathy, with a first difference value of .020 .

Of the variables that predicted a lack of sympathy for the Taliban, being of Tajik ethnicity was most predictive, with a first difference value of .040 . This variable is followed by those who have experienced violence, with a first difference value of .027 . Being female was the next most predictive variable for opposition to the Taliban, with a first difference value of .020 . Of equal predictive power were the variables for Hazara and Uzbek ethnicity, with first difference values 
of .020. Rounding out the significant predictors of opposition to the Taliban was those who said their finances were worse over the last year, with a first difference value of .014.

In Table 4, we show the result for the same model but using only data from Afghan Pashtuns. This model used a subsample of 4,203 Pashtun respondents. Figure 7 provides a coefficient plot with 95 percent confidence intervals.

Table 4: Sympathy for the Taliban Ordered Probit Model: Pashtuns Only

Dependent Variable: Sympathy for the Taliban

\begin{tabular}{|c|c|c|}
\hline Independent Variables & Coefficient (SE) & First Difference \\
\hline Rural resident & $0.352(0.060)^{* * *}$ & .051 \\
\hline District & $-0.001(0.000)^{* * *}$ & .102 \\
\hline Better finances & $0.009(0.028)$ & \\
\hline Fear for security & $0.096(0.019)^{* * *}$ & .071 \\
\hline Family victim & $-0.146(0.045)^{* *}$ & .030 \\
\hline Gender & $-0.198(0.046)^{* * *}$ & .031 \\
\hline Age & $0.001(0.002)$ & \\
\hline Education & $0.021(0.018)$ & \\
\hline Income & $-0.000(0.000)^{*}$ & .110 \\
\hline Cut 1 & $-0.929(0.140)^{*}$ & \\
\hline $\mathrm{N}$ & 4,203 & \\
\hline Log Likelihood & -3126.514 & \\
\hline Prob $<$ chi 2 & 0.000 & \\
\hline
\end{tabular}




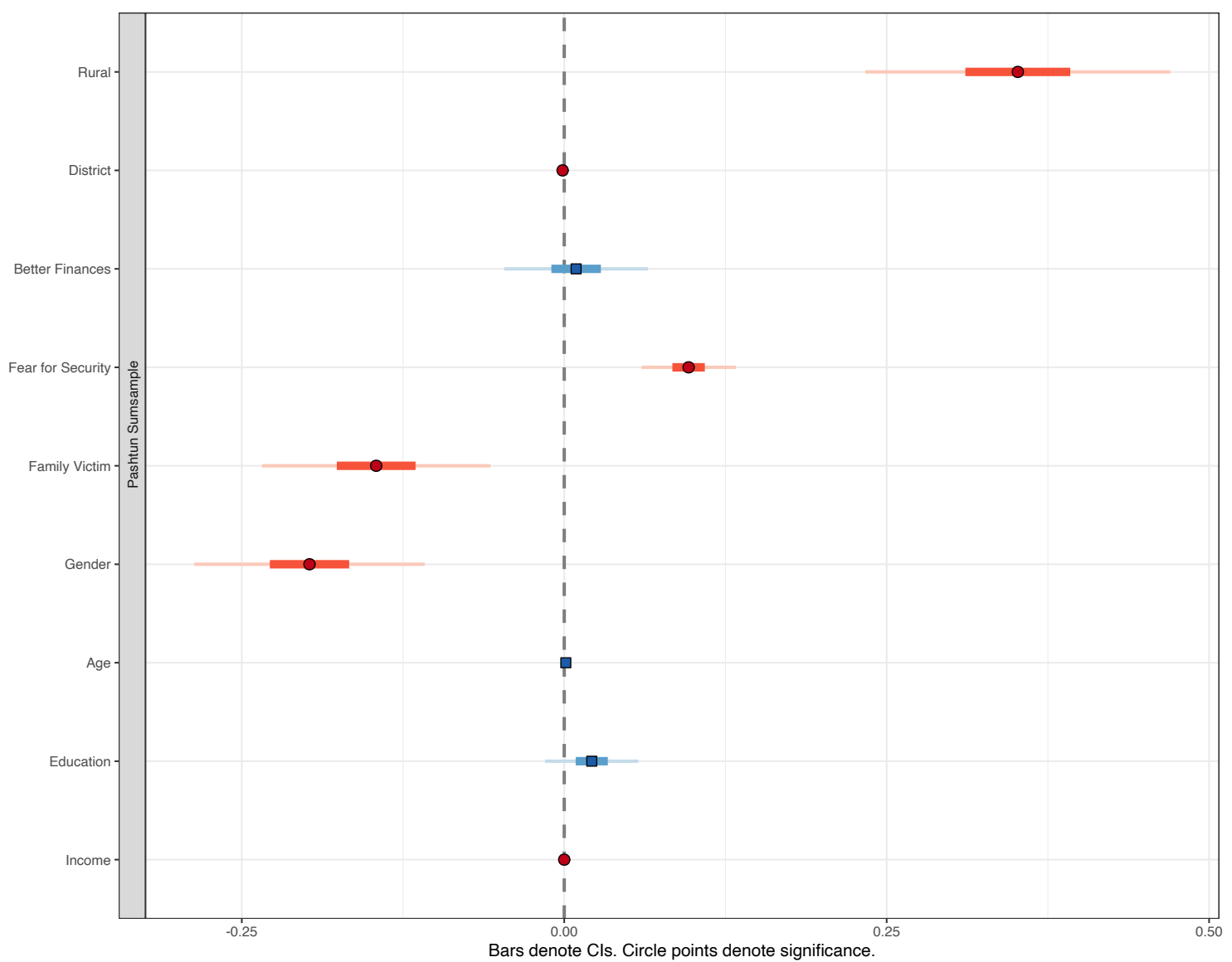

Figure 7: Coefficient Plot for Pashtun Subsample

The results of the ordered probit analysis for the Pashtun sample are very similar to the full-respondent model. None of the signs switch direction on the coefficients, meaning that there are no changes in the results compared to the predicted effects. The only meaningful change in the ordered probit results is that the variable for the assessment of the household financial situation is not statistically significant.

The results of the first differences analysis among Pashtuns provide even stronger empirical support for the arguments about basic needs made in this study than using the whole of Afghanistan sample. The need for security is by and far the most important predictor of sympathy for the Taliban among Pashtuns, with a first difference value of .070. 
In the Pashtun sample, among the control variables, being a wealthier Pashtun is the strongest predictor of sympathy for the Taliban, with a first difference value of .110. Being a rural Pashtun follows in predictive power with a first difference value of .051 . The variable for district was also very predictive with a first difference value of .102, although this difficult to interpret other than district effects strongly influence how Pashtuns view the Taliban.

In terms of the variables that predict opposition to the Taliban, being a victim of a crime (.030) was nearly identical in predictive power to the variable for female, which has a first difference value of .031. Unsurprisingly, female Pashtuns and those who have suffered violence, were most likely to oppose the Taliban insurgency. This effect is consistent with the associations between Taliban sympathy, gender, and family victimization we found in the all-Afghan model.

\section{Conclusion}

During wartime many civilians either flee their homes or are forcibly displaced from their communities. Those who remain, however, face the dilemma of supporting the "best worst" option for local governance. Perceived insecurity and fear of future victimization only exacerbate this dilemma, as civilians are forced to make life-or-death choices under conditions of stress, fear, and uncertainty. In the face of these barriers, noncombatants decide who to support based on their perceptions about the most effective and reliable option for local governance. Insurgents recognize this calculus, and seek to persuade the local population through heavy-handed tactics which reinforce their reputation as a more desirable alternative than the incumbent regime. The logic of the "heavy-handed insurgent" is most powerful when insurgents and civilians share a common social identity, which further cements social trust and confidence in protection. 
The collapse of the Afghan government during the U.S. withdraw in August 2021 provides compelling evidence for the paradox of the heavy-handed insurgent. Despite contributing to largescale indiscriminate violence in Pashtun communities, a majority of Afghan civilians perceived the Taliban to provide competent governance in the absence of Coalition or Afghan forces. This consensus was shared among members of the Afghan security forces, with an estimated 80 percent of nearly 250,000 Afghan army and national police personnel surrendering, deserting, or switching-sides over the span of 11 days. ${ }^{29}$ The dramatic shift in civilian behavior over the course of the US withdrawal is unsurprising given past public opinion trends in the Asia Foundation's Survey of the Afghan People. In regression analysis of the 2018 survey wave, we find strong empirical support for sympathy for the Taliban among the most vulnerable, conflict-affected Pashtun communities. The paradox of the heavy-handed insurgent reveals that insurgents can actually win public support by driving feelings of insecurity if they foster a reputation for maintaining security in the areas they control. Selective violence and civilian victimization are the strongest predictors of public opposition to insurgency. However, such strategies are unlikely among insurgents and civilians who share a common social identity.

The implications of our findings for understanding civilian behavior during wartime are profound. While this study was not about why insurgencies start or escalate, it is widely believed that public support for insurgents is necessary for them to succeed. What this study shows is that noncombatants make sophisticated judgements about which armed actors will be able to provide competent and effective governance over the long run. Despite two decades of massive financial and human investment in the Kabul government by US and allied governments, the average Afghan civilian keenly understood the limits of counterinsurgents' resolve and the Afghan security forces' capacity. While Taliban forces contributed to indiscriminate violence in vulnerable 
communities, they maintained a credible commitment to provide security in the territories under their control.

Now that the Taliban controls the Afghan state, civilians across the country will revise their expectations regarding the government's ability to provide consistent governance. As the Islamic State's affiliate in Afghanistan (Islamic State - Khorasan Province) seeks to challenge Taliban rule, the Taliban must first establish a reputation as competent and effective security providers before generating public trust and confidence. Given the Islamic State's status as a foreign insurgent force within Afghanistan, the next stage of the conflict will provide new opportunities to refine the logic of the heavy-handed insurgent. 


\section{Bibilography}

Beath, A., Fotini C., Egorov, G and Enikolopov, R. Electoral rules and the quality of politicians: theory and evidence from a field experiment in Afghanistan. No. w20082. National Bureau of Economic Research, (2014).

Berman, E., Shapiro, J., \& Felter, J. "Can hearts and minds be bought? The economics of counterinsurgency in Iraq.” Journal of Political Economy 119, no.4 (2011): 766-819.

Biddle, S. and Zhukov, Y."Afghanistan's security forces unraveled this month. What broke their seven-year stalemate with the Taliban?" The Washington Post, accessed at https://www.washingtonpost.com/politics/2021/08/31/afghanistans-security-forces-unraveledthis-month-what-broke-their-seven-year-stalemate-with-taliban/. (2021).

Branscombe, N., Wann, D., Noel, J., \& Coleman, J. "In-group or out-group extremity: Importance of the threatened social identity." Personality and Social Psychology Bulletin, 19, no. 4 (1993): 381-388.

Böhnke, J., Koehler, J., \& Zürcher, C. "State formation as it happens: insights from a repeated cross-sectional study in Afghanistan, 2007-2015." Conflict, Security \& Development 17, no. 2 (2017): 91-116.

Condra, Luke N., and Jacob N. Shapiro. "Who takes the blame? The strategic effects of collateral damage." American Journal of Political Science 56, no. 1 (2012): 167-187.

Condra, L., Felter, J., Iyengar, R., \& Shapiro, J. The effect of civilian casualties in Afghanistan and Iraq (No. w16152). National Bureau of Economic Research. (2010).

Davis, P., Larson, E., Haldeman, Z, Oguz, M., and Rana, Y. Understanding and influencing public support for insurgency and terrorism. Washington, D.C.: RAND Corporation. (2012).

Ellemers, N., Spears, R., \& Doosje, B. "Self and social identity." Annual Review of Psychology, 53, no.1 (2002): 161-186.

Farrell, T., \& Giustozzi, A. "The Taliban at war: inside the Helmand insurgency, 20042012.” International Affairs, 89, no.4 (2013): 845-871.

Giustozzi, A. "Hearts, Minds, and the Barrel of a Gun: The Taliban's Shadow Government." Prism, 3, no.2 (2012): 71-80.

Hanania, R. "Establishing causality in counter-Insurgency doctrine: a theoretical and empirical analysis of population-centric war." Presented at the Emerging Scholars Conference at the Notre Dame International Security Center. (2019).

Hazelton, J. L. Bullets Not Ballots: Success in Counterinsurgency Warfare. New York: Cornell University Press. (2021). 
Juergensmeyer, M. Terror in the Mind of God: The global rise of religious violence. Berkeley, CA: University of California Press. (2017).

Jones, S. The rise of Afghanistan's insurgency: State failure and Jihad.” International Security, 32, no.4 (2008): 7-40.

Jones, S. G. In the graveyard of empires: America's war in Afghanistan. WW Norton \& Company. (2010).

Kaltenthaler, K., \& Miller, W. and Fair, C. "Ethnicity, Islam, and Pakistani Public Opinion toward the Pakistani Taliban." Studies in Conflict \& Terrorism, 38, no. 11 (2015): 938-957.

Kaplan, O. Resisting War: How communities protect themselves. New York: Cambridge University Press. (2017).

Knuppe, A. J. "Blowback or Overblown: Why civilians under threat support invasive foreign intervention.” Journal of Peace Research, forthcoming, Autumn 2021.

Kruglanski, A. W., Gelfand, M. J., Bélanger, J. J., Sheveland, A., Hetiarachchi, M., \& Gunaratna, R. "The psychology of radicalization and deradicalization: How significance quest impacts violent extremism." Political Psychology, 35 (2014): 69-93.

Kruglanski, A. W., Gelfand, M., \& Gunaratna, R. "Terrorism as means to an end: How political violence bestows significance", in Meaning, Mortality, and Choice: The Social Psychology of Existential Concerns, edited by P. R. Shaver and M. Mikulincer, American Psychological Association. (2012).

Kruglanski, A., Gelfand, M., Bélanger, J., Sheveland, A., Hetiarachchi, M., \& Gunaratna, R. The psychology of radicalization and deradicalization: How significance quest impacts violent extremism. Political Psychology, 35 (2014): 69-93.

Kruglanski, A. W., Bélanger, J. J., \& Gunaratna, R. The Three Pillars of Radicalization: Needs, Narratives, and Networks. Oxford University Press, USA. (2019).

Lyall, J., Blair, G., \& Imai, K. "Explaining support for combatants during wartime: A survey experiment in Afghanistan." American Political Science Review, 107, no. 4 (2013): 679-705.

Lyall, J., Zhou, Y. Y., \& Imai, K. "Can economic assistance shape combatant support in wartime? Experimental evidence from Afghanistan.” American Political Science Review, 114, no.1, (2020): 126-143. 
Mikulaschek, C., Pant, S., \& Tesfaye, B. "Winning hearts and minds in civil wars: Governance, leadership change, and support for violent groups in Iraq." American Journal of Political

Science, 64, no. 4 (2020): 773-790.

Nagl, J. A., Amos, J. F., Sewall, S., \& Petraeus, D. H. The US Army/Marine corps counterinsurgency field manual. University of Chicago Press. (2008).

Petersen, R. D. Resistance and rebellion: lessons from Eastern Europe. New York: Cambridge University Press. (2001).

Shaver, A., \& Shapiro, J. "The effect of civilian casualties on wartime informing: Evidence from the Iraq war." Journal of Conflict Resolution, 65, no.7-8 (2021): 1337-1377.

Stollenwerk, E. Securing Legitimacy? Perceptions of Security and ISAF's Legitimacy in Northeast Afghanistan. Journal of Intervention and Statebuilding, 12, no.4 (2018): 506-526.

Tajfel, H. "Experiments in intergroup discrimination." Scientific American, 223, no.5 (1970): 96103.

Tajfel, H. Individuals and groups in social psychology. British Journal of Social and Clinical Psychology, 18, no.2 (1979): 183-190.

Tanis, M., \& Postmes, T. “A social identity approach to trust: Interpersonal perception, group membership and trusting behaviour." European Journal of Social Psychology, 35, no.3 (2005): 413-424.

Weinstein, J. M. Inside rebellion: The politics of insurgent violence. Cambridge University Press. (2006)

\section{Funding details}

This work did not receive any financial assistance from an external funding agency or grant.

\section{Disclosure statement}

No potential conflict of interest was reported by the author.

\section{Notes on contributor}

Karl Kalthenthaler (Ph.D.) is a Professor of Political Science at the University of Akron and Director of the Center for Intelligence and Security Studies. He specializes in international security issues, violent extremism, and the politics of the Middle East and South Asia. He has served as a consultant to the US State Department, the US military, and other government agencies on issues related to US foreign policy in the Middle East and South Asia.

Arie W. Kruglanski (Ph.D.) is a Distinguished University Professor of Psychology at the University of Maryland, College Park and a Fellow of the American Psychological Association 
and Association of Psychological Science. His interests include Lay Epistemology and Goal Systems, among many others.

Austin J. Knuppe (Ph.D.) is an Assistant Professor of Political Science at Utah State University and one of the co-founders of the Conflict to Peace Lab (C2P) at the Mershon Center for International Security Studies at The Ohio State University. His research interests include the role of civilian judgement and decision making during civil conflict, as well as the intersection of religion and international politics.

${ }^{1}$ UNAMA (United Nations Assistance Mission in Afghanistan) Afghanistan Annual Report on Protection of Civilians in Armed Conflict: 2019.

${ }^{2}$ Davis, Larson, Haldeman, Oguz, and Rana. Understanding and Influencing Public Support for Insurgency and Terrorism.

${ }^{3}$ Beth, Christia, Egorov, and Enikolopov. "Electoral rules and the quality of politicians: theory and evidence from a field experiment in Afghanistan"; Condra and Shapiro. "Who takes the blame? The strategic effects of collateral damage."; Lyall, Zhou. and Imai "Can economic assistance shape combatant support in wartime? Experimental evidence from Afghanistan."

${ }^{4}$ Petersen, Resistance and rebellion: lessons from Eastern Europe; Knuppe, "Blowback or Overblown: Why civilians under threat support invasive foreign intervention."

${ }^{5}$ Kaplan, Resisting War: How communities protect themselves.

${ }^{6}$ See: Kaltenthaler, Miller, and Fair, "Ethnicity, Islam, and Pakistani Public Opinion toward the Pakistani Taliban."; Lyall, Blair, and Imai, "Explaining support for combatants during wartime: A survey experiment in Afghanistan."

${ }^{7}$ Weinstein, Inside rebellion: The politics of insurgent violence

${ }^{8} \mathrm{Nagl}$, Amos, Sewall, and Petraeus, The US Army/Marine corps counterinsurgency field manual.

${ }^{9}$ Hazelton, Bullets not ballots: Success in counterinsurgency warfare.

${ }^{10}$ Berman, Shapiro, and Felter, "Can hearts and minds be bought? The economics of counterinsurgency in Iraq."

${ }^{11}$ Mikulaschek, Pant, and Tesfaye, "Winning hearts and minds in civil wars: Governance, leadership change, and support for violent groups in Iraq."

${ }^{12}$ Lyall, Zhou. and Imai "Can economic assistance shape combatant support in wartime? Experimental evidence from Afghanistan." 
${ }^{13}$ Stollenwerk "Securing Legitimacy? Perceptions of Security and ISAF's Legitimacy in Northeast Afghanistan.”

${ }^{14}$ Mikulaschek, Pant, and Tesfaye, "Winning hearts and minds in civil wars: Governance, leadership change, and support for violent groups in Iraq."

${ }^{15}$ Böhnke, J., Koehler, J., \& Zürcher, C. “State formation as it happens: insights from a repeated cross-sectional study in Afghanistan, 2007-2015."

${ }^{16}$ Beth, Christia, Egorov, and Enikolopov. "Electoral rules and the quality of politicians: theory and evidence from a field experiment in Afghanistan"

${ }^{17}$ Hanania, "Establishing Causality in Counter-Insurgency Doctrine: A Theoretical and Empirical Analysis of Population-Centric War."

${ }^{18}$ Lyall, J., Blair, G., \& Imai, K. "Explaining support for combatants during wartime: A survey experiment in Afghanistan;" Shaver, A., \& Shapiro, J. "The effect of civilian casualties on wartime informing: Evidence from the Iraq war."

${ }^{19}$ Condra and Shapiro, "Who takes the blame? The strategic effects of collateral damage."

${ }^{20}$ Condra, Felter, Iyengar, and Shapiro, The effect of civilian casualties in Afghanistan and Iraq.

${ }^{21}$ Shaver and Shapiro, "The effect of civilian casualties on wartime informing: evidence from the Iraq war."

${ }^{22}$ Giustozzi, "Hearts, Minds, and the Barrel of a Gun: The Taliban's Shadow Government."

${ }^{23}$ Farrell and Giustozzi, "The Taliban at war: inside the Helmand insurgency, 2004-2012"; Jones, "The rise of Afghanistan's insurgency: State failure and Jihad"; Jones, In the graveyard of empires: America's war in Afghanistan.

${ }^{24}$ Kruglanski, Gelfand, and Gunaratna, "Terrorism as means to an end: How political violence bestows significance"; Kruglanski, A., Gelfand, M., Bélanger, J., Sheveland, A., Hetiarachchi, M., \& Gunaratna, R. "The psychology of radicalization and deradicalization: How significance quest impacts violent extremism."; Kruglanski, Belanger, and Gunaratna, The Three Pillars of Radicalization: Needs, Narratives, and Networks.

${ }^{25}$ Kruglanski, Belanger, and Gunaratna, The Three Pillars of Radicalization: Needs, Narratives, and Networks.

${ }^{26}$ Tajfel, "Experiments in intergroup discrimination.”; Tajfel,’Individuals and groups in social psychology."; Branscombe, Wann, Noel, and Coleman, "In-group or out-group extremity: Importance of the threatened social identity."; Ellemers, Spears, and Doosje, "Self and social identity." 
${ }^{27}$ Tanis, and Postmes, "A social identity approach to trust: Interpersonal perception, group membership and trusting behaviour."

${ }^{28}$ Replication data and R code are available at the Open Science Framework (OSF) repository for this project located at [URL].

${ }^{29}$ Biddle \& Zhukov, “Afghanistan's security forces unraveled this month. What broke their seven-year stalemate with the Taliban?" 